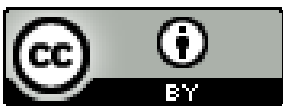

\title{
MIGRATION IN BRAZILIAN AFRO-DESCENDANTS
} COMMUNITIES: A NEW APPROACH TO ILLUSTRATE THE MEANING OF CONTEMPORARY QUILOMBO

\author{
Sabrina Guimarães Paiva ${ }^{1}$ \\ Carolina Carvalho Gontijo ${ }^{2}$ \\ Raquel Carvalho Gontijo ${ }^{3}$ \\ Lorena Madrigal ${ }^{4}$ \\ Maria de Nazaré Klautau-Guimarães ${ }^{5}$ \\ Silviene Fabiana de Oliveira ${ }^{6}$
}

Resumo: African-descendant populations in Latin America are heterogeneous in their history, culture, and genetic ancestry. In Brazil, these communities are known as quilombos. They were at first established as places of resistance to slavery in rural areas. However, others were formed as a result of a recent immigration. This has given rise to the discussion of how well all such groups fit the contemporary meaning of quilombo. We draw on evidence from field research in Central Brazil region to illustrate two examples of quilombos, a quilombo with families in the community for at least three generations, and others that are related to migration of Black communities. We call for an expansive meaning of quilombo that accommodates the historical diversity of these communities.

\footnotetext{
${ }^{1}$ Professora, Instituto Federal de Educação, Ciência e Tecnologia do Tocantins (IFTO), Campus Araguaína, Professora colaboradora do Programa de Pós-Graduação em Demandas Populares e Dinâmicas Regionais, Universidade Federal do Tocantins (UFT), Campus Araguaína, Tocantins, Brasil, sabrinapaiva@ifto.edu.br

2 Pesquisadora, Programa de Pós-Graduação em Biologia Animal, Instituto de Ciências Biológicas, Universidade de Brasília, Brasília, DF, Brasil.

${ }^{3}$ Antropóloga e cientista social, Instituto de Direito Público - IDP, Brasília, DF, Brasil.

${ }^{4}$ Professor, Department of Anthropology, University of South Florida, Tampa, FL, United States.

${ }^{5}$ Professora associada, Laboratório de Genética, Departamento de Genética e Morfologia, Instituto de Ciências Biológicas, Universidade de Brasília (UNB) e Programa de Pós-Graduação em Ensino de Ciências, Instituto de Ciências Biológicas, Universidade de Brasília, Brasília, Distrito Federal, Brasil.

${ }^{6}$ Professora associada, Laboratório de Genética, Departamento de Genética e Morfologia, Instituto de Ciências Biológicas, Universidade de Brasília (UNB) e Programa de Pós-Graduação em Biologia Animal, Instituto de Ciências Biológicas, Universidade de Brasília (UNB), Brasília, Distrito Federal, Brasil, silviene.oliveira@gmail.com
} 
Keywords: quilombo; Brazil; migration; Afro-derived community

\section{MIGRAÇÃO EM COMUNIDADES AFRO-DESCENDENTES BRASILEIRAS: UMA NOVA ABORDAGEM PARA ILUSTRAR O SIGNIFICADO DE QUILOMBO CONTEMPORÂNEO}

Resumo: As populações Afro-descendentes na América Latina são heterogêneas em sua história, cultura e ancestralidade genética. No Brasil, essas comunidades são conhecidas como quilombos. Elas foram inicialmente estabelecidas como lugares de resistência à escravidão nas áreas rurais. No entanto, outros foram formados como resultado de um processo de imigração recente. Com isso, iniciou-se uma discussão sobre como todos esses grupos populacionais se encaixam no significado contemporâneo de quilombo. Nós nos baseamos em evidências de pesquisa de campo na região central do Brasil para ilustrar dois exemplos de quilombos, um quilombo com famílias presentes na comunidade por pelo menos três gerações e outros que estão relacionados à migração de comunidades negras. Destacamos um significado ampliado de quilombo, que acomoda a diversidade histórica dessas comunidades.

Palavras-chave: quilombo; Brasil; migração; comunidade afro-derivada

\section{LA MIGRACIÓN EN LAS COMUNIDADES DE AFRODESCENDIENTES DE BRASIL: UN NUEVO ENFOQUE PARA ILUSTRAR EL SIGNIFICADO DEL QUILOMBO CONTEMPORÁNEO}

Resumen: Las poblaciones afrodescendientes en América Latina son heterogéneas en su historia, cultura y ascendencia genética. En Brasil, estas comunidades son conocidas como quilombos. Al principio se establecieron como lugares de resistencia a la esclavitud en las zonas rurales. Sin embargo, otros se formaron como resultado de una inmigración reciente. Esto ha dado lugar a la discusión de qué tan bien todos estos grupos encajan con el significado contemporáneo de quilombo. Nos basamos en la evidencia de la investigación de campo en la región del centro de Brasil para ilustrar dos ejemplos de quilombos, un quilombo con familias en la comunidad durante al menos tres generaciones, y otros que están relacionados con la migración de comunidades negras. Destacamos un significado expansivo de quilombo que acomode la diversidad histórica de estas comunidades.

Palabras-clave: quilombo; Brasil; migración; comunidad Afro-derivada

\section{MIGRATION DANS LES COMMUNAUTÉS D'ASCENDANCE AFRICAINE AU BRÉSIL: UNE NOUVELLE APPROCHE POUR ILLUSTRER LA SIGNIFICATION DU QUILOMBO CONTEMPORAINE}

Résumé: Les populations d'ascendance africaine en Amérique Latine sont hétérogènes quant à leur histoire, leur culture et leurs origines génétiques. Au Brésil, ces communautés sont connues sous le nom de quilombos. Au début, ils se sont établis comme des lieux de résistance à l'esclavage dans les zones rurales. Cependant, d'autres ont été formés à la suite de l'immigration récente. Cela a conduit à la discussion sur l'adéquation de tous ces groupes avec la signification contemporaine de quilombo. Nous appuyons sur les preuves issues de la recherche sur le terrain dans le centre du Brésil pour illustrer deux exemples de quilombos, un quilombo avec des familles de la communauté depuis au moins trois générations, et d'autres liés à la migration des communautés noires. Nous soulignons une signification élargie de quilombo qui tient compte de la diversité historique de ces communautés.

Mots-clés: quilombo; Brésil; migration; communauté d'origine africaine 


\section{INTRODUCTION}

The proportion of African-derived people in different Latin-American countries varies widely. A total population ranging from 80 to 150 million people was estimated from data from different sources, including United Nations Children's Fund (UNICEF), The World Bank Group, the Economic Commission for Latin America and the Caribbean, among others (Antón et al., 2009).

During the Latin American period of slavery (1490-1888), communities were founded by run-away or by abandoned former slaves in rural or jungle areas. These populations are tied to slavery resistance and are known by different names in different countries, such as quilombos in Brazil, cumbes in Venezuela, palenques in Cuba and Colombia, marrons in Jamaica, bush negroes in Suriname, and cimaronaje in Cuba and Puerto Rico. These terms may be equivalent to quilombo, meaning the pursuit of freedom, rebellion and resistance against oppression or run-away slaves (Gomes, 2015; Florentino and Amantino, 2012). In Brazil, there are many names for these communities besides quilombos, namely mocambos, comunidades negras (Black communities), comunidades negras rurais (Rural Black communities), comunidades Afro-descendentes (Africandescendant communities), Terra de pretos (Black's land), and Afro-derived communities. The term quilombo appears initially associated with Quilombo de Palmares (a historical African refugee settlement in Alagoas, Brazil), possibly an allusion to its political organization, similar to Angolan quilombos in Central Africa (Lara, 2010; Filho and Germani, 2014). The classic definition of quilombo dates back to the 18th century and describes these communities as formed by run-away slaves who escaped from their slavers and hid in difficult-to-reach areas, which in Brazil are referred to as "the territory" (Chagas, 2001; Torre, 2013).

While quilombos have existed for hundreds of years, only in recent decades have they have intensified their efforts to make legal claims and gain titles to their ancestral lands. Unfortunately, they have encountered numerous obstacles, many of which stem from disagreements over the definition of a quilombo, as well as from their socially and economically marginalized position within Brazil (Center, 2008). Furthermore, they have encountered difficulties in finding records or other evidence supporting these claims (Fiabani, 2008). Because the definition of what a quilombo is affects the application of laws granting land rights to these communities, as well as access to other affirmative 
action benefits, quilombo representatives seek an expansive definition that accommodates the historical diversity in these communities, while groups with interest in conflict with their rights seek to restrict this definition. It is noteworthy that in Brazil there are also African-derived communities which do not consider themselves to be quilombos, because they do not have historical or cultural bases to define themselves. These kind of AfroBrazilian groups may or may not be rural (Anjos, 2011; SEPPIR, 2012). Moreover, there are communities that do not wish to be associated with the quilombo identity because to them it means a return to the slavery system (Silva, 2011; Mattos, 2006).

After decades of historical and anthropological studies and of political and social movements, the definition of quilombo has been expanded, and according to the Brazilian Association of Anthropology, it does not comprise a single social formation, immutable and fixed in time (ABA, 2012). The Black Movement from the 1960's-1970's, together with academic representatives, began a political and ideological struggle to unmask racism in Brazilian society, and to show racial differences in socioeconomic and demographic contexts (Popolo et al., 2011) and to repair a historical debt of Brazilian society with the descendants of slaves. The Black Movement promoted the identification of African-descendants with their historical sense of 'pertencimento' (to belong), or membership, in the African diaspora. In this moment, 'quilombo' was associated to a form of mobilization and struggle for freedom and citizenship, as well as for political, economic and social liberation (Leite, 2015).

Currently, the Brazilian legal system recognizes 'Remnants of quilombos', as ethno-racial groups, according to self-classification criteria, each with their own historical trajectory, associated to their own land, established as part of the resistance to oppression, and with presumed African ancestry related to resistance suffered during historic oppression.

More than 2,600 Afro-derived communities spread around of the country, are recognized by the government as quilombos (Fundação Cultural Palmares, 2016), the majority of which are located in Central Brazil region, where a combination of the ecology, topography and absent army contributed to the establishment of many quilombos (Karash, 1996). This region is known as Chapada dos Negros (Black people highland) and has about seventy seven quilombos communities, the majority of whose inhabitants descend from slaves from mining camps (Lopes, 2009; Fundação Cultural Palmares, 2016). 
More than a century after the abolition of slavery in Brazil, the term 'quilombo' continues to evolve new meanings, not all of them associated with its common definition as a runaway slave community (Leite, 2015). This has given rise to the discussion how all such groups fit the contemporary meaning of quilombo and the relation between quilombo definition and the political recognition as well struggle for land rights. Therefore, the purpose of this study is to illustrate the contemporary meaning of quilombo using the historical circumstances and the diversity in the migration patterns of three quilombos with different levels of urbanization located in Central Brazil region: an urban, a non-isolated rural and an isolated rural. These quilombos are registered by the Brazilian governmental institute (Fundação Cultural Palmares) as a recognition of their full quilombo status.

\section{METHODS}

We conducted a cross-sectional population-based study in three quilombos: Cocalinho, Pé do Morro, and Kalunga. The geographic locations of these three quilombos are shown in the Figure 1. Cross-sectional study design is a type of observational study design. In a cross-sectional population-based study, the investigator measures the outcome and the exposures in the study participants at the same time in each study population. The participants in a cross-sectional study are selected based on the inclusion and exclusion criteria set for the research. These studies are used for population-based surveys and can usually be conducted relatively faster and are inexpensive (Setia, 2016). Cocalinho, a non-isolated rural village, and Pé do Morro, an urban community, have about 700 and 600 inhabitants, respectively. Both are located in the Araguaia River Basin, North region of Brazil. Kalunga, an isolated rural community, has a population of about 5300 habitants and is one of the largest quilombo communities in Brazil. The community covers an area of approximately 258,000 hectares in the countryside of the state in the Middle West region. It is partitioned into several villages, which are scattered throughout the Kalunga territory, without a marked geographical isolation between them. 
Figure 1: Map of Brazil showing the five administrative regions and the location of the quilombo communities here mentioned.

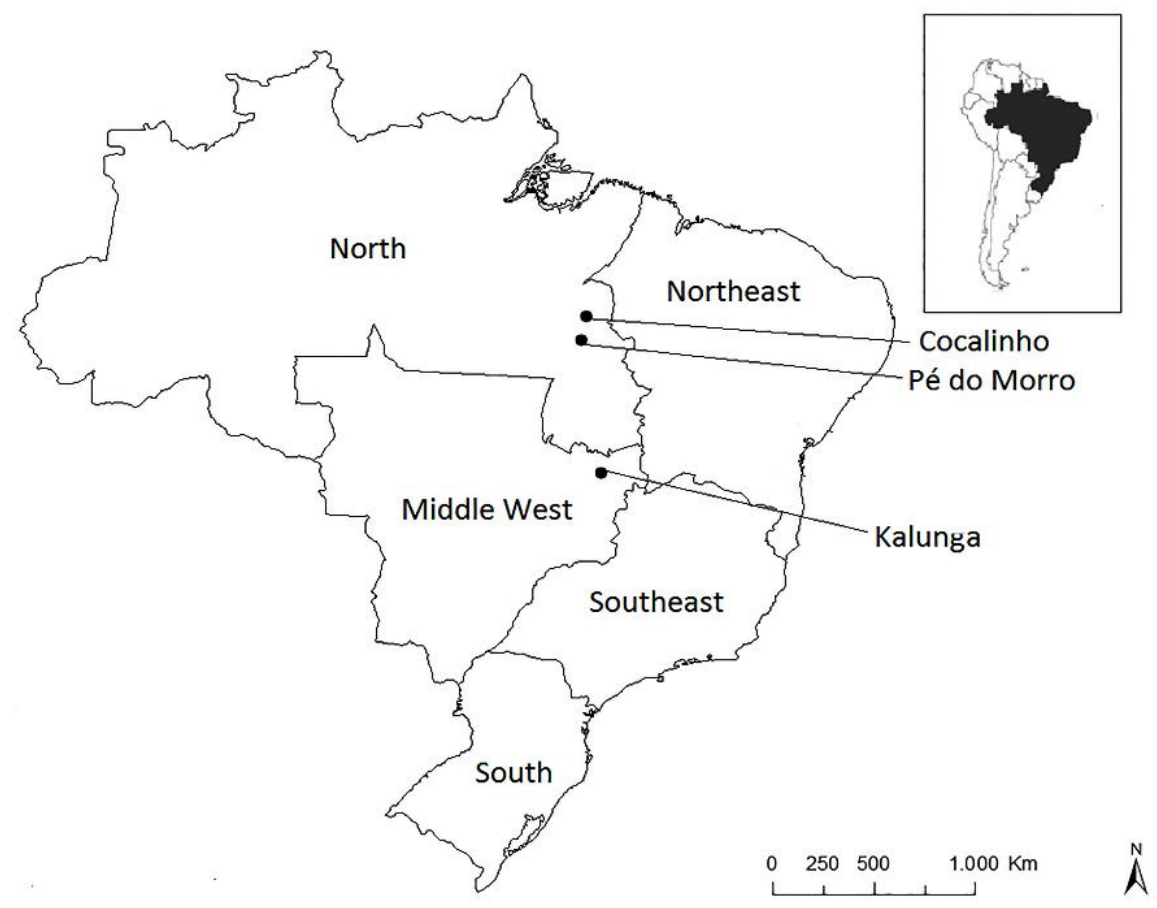

Source: Public Domain with adaptation by authors

A total of 347 individuals over the age of 18 that live in these communities, 214 in Kalunga, 70 in Cocalinho, and 63 in Pé do Morro, were interviewed using a questionnaire specially designed to this study. The participants were asked about their own phenotypic classification, using the self-classification categories of the Brazilian Institute of Geography and Statistics - Census of 2010 (IBGE, 2011). Aiming to determine if the three communities self-classified differently from the communities around them, we compared our data to the Brazilian census of 2010. Comparisons were performed considering states - Goiás vs Kalunga; Cocalinho vs Tocantins; Pé do Morro vs Tocantins -, and nearby municipalities - Cavalcante vs Kalunga; Santa Fé do Araguaia vs Cocalinho; Aragominas vs Pé do Morro.

All participants were informed about the objectives of the work, procedures, and confidentiality of data, and expressed their agreement to participate in the research by signing the Instrument of Consent, according to a protocol approved by the Research Ethics Committee of the Faculty of Health Sciences at the University of Brasilia (CEPFS/UnB 214/13). 
The following variables were collected: age, gender, place of birth, phenotypic self-classification, and number of marriages. We defined native individuals as those who were born into the community. The female/male ratio between natives and immigrants was determined. All participants who reported having a spouse, were additionally asked about the place of birth of the spouse. We also asked about the reason for migrating into their current place of residency. Moreover, we collected these data across three generations to provide evidence about the historical formation. Each individual was asked about the place of birth of their parents and grandparents. The participants who were interviewed were called generation 3 (G3), and participants' parents and grandparents were called generations $2(\mathrm{G} 2)$ and $1(\mathrm{G} 1)$, respectively. We estimated the proportion of couples formed by two native members (named endogamous), by a native member and a migrant (exogamous) and by two migrant members (migrants). The number of each type of marriage was obtained by direct counting. Among exogamous marriages, we estimated the proportion of patrilocal (native men married with migrant women) and matrilocal (native women married with migrant men) marriages. From that, it was possible to determine the ratio of the number of patrilocal to matrilocal unions ( $\mathrm{P}$ and $\mathrm{M}$ index) (Amorim et. al., 2011).

We chose a sampling strategy based on estimates of number of families in each community. Traditionally, quilombo families are large with more than four generations living in the same house. The sample of this study included at least two members of each family, generally the oldest couple of the house.

Analyses were performed using IBM SPSS 2.0 software (SPSS, Chicago, IL, USA) and SAS statistical software, version 9.4 (Stata Corp., College Station, United States). Comparisons between categorical variables (gender, migration pattern and phenotypic self-classification) were tested in pairs by Chi-square test of Pearson and Fisher's Exact Test while quantitative variables (age) were analyzed using Wilcoxon test $(\mathrm{p} \leq 0.05)$. All continuous quantitative variables were tested for normality.

\section{RESULTS}

The distribution of migrants and natives was not the same across the three quilombos (Table 1). Kalunga is the community with the highest frequency of nativeborn individuals. We observed a significant difference in the proportion of men and women between natives and migrants in Cocalinho, with a higher number of migrant men 
and native women. In contrast, in Pé de Morro there was no difference in the proportion of migrant men and women, while in Kalunga we did not observe any migrant women.

Table 1 Distribution of the proportion of men and women, natives and immigrants in the three quilombos.

\begin{tabular}{|c|c|c|c|c|c|c|}
\hline \multirow{3}{*}{ Quilombo } & \multirow{3}{*}{$\begin{array}{l}\text { Migratio } \\
\text { n }\end{array}$} & \multicolumn{4}{|c|}{ Gender } & \multirow[b]{2}{*}{ p value } \\
\hline & & \multicolumn{2}{|c|}{ Women } & \multicolumn{2}{|c|}{ Men } & \\
\hline & & $\mathbf{N}$ & $\%$ & $\mathbf{N}$ & $\%$ & \multirow{3}{*}{0.0915} \\
\hline \multirow{2}{*}{ Kalunga } & Immigran & -- & -- & 3 & 3.1 & \\
\hline & Native & 117 & 100.0 & 94 & 96.9 & \\
\hline \multirow{2}{*}{ Cocalinho } & $\begin{array}{l}\text { Immigran } \\
\mathrm{t}\end{array}$ & 31 & 73.8 & 27 & 96.4 & \multirow[t]{2}{*}{0.0209} \\
\hline & Native & 11 & 26.2 & 1 & 3.6 & \\
\hline \multirow{2}{*}{ Pé do Morro } & Immigran & 35 & 94.6 & 24 & 92.3 & \multirow[t]{2}{*}{1.0000} \\
\hline & Native & 2 & 5.4 & 2 & 7.7 & \\
\hline
\end{tabular}

Source: authors, 2019.

We observed a significant proportion of immigrants over 70 years of age in Pé do Morro when compared to native individuals $(\mathrm{p}=0.001)$, indicating an association between migration and age group. This relationship was not present in either of the other two populations (data not shown). Differences were observed in the distributions of phenotypic self-classification between Brazilian's census and the three quilombos communities ( $\mathrm{p} \approx 0.000$ ) (Table 2$)$. Our data indicated that the proportion of people who consider themselves to descend from African ancestors was higher in the three communities than in urban areas. We observed a higher proportion of Black selfclassification (between 34.92 to $57.97 \%$ ) and lower proportion of White selfclassification (between 0.97 to $11.43 \%$ ) in the three quilombos than in nearby cities and surrounding regions.

The categories of marriages over the past three generations are shown in Table 3. All information about three generations was accessed from generation 3. It was possible to access data from 87 couples for G1, 52 for G2, and 46 for G3 in Cocalinho while in Pé do Morro it was accessed 70 couples for G1, 52 for G2, and 40 for G3. In Kalunga, it was possible to access data from 242 couples for G1, 133 for G3, and 126 for G3.

The highest proportion of endogamous marriages across the three generations was observed in Kalunga, the isolated rural community. The few marriages that took place 
between migrants were observed in generations 1 (14 - 5.78\%) and 2 (six - 4.51\%), while the exogamous marriages across the three generations were mostly matrilocal. In contrast, marriages between migrants were prevalent in all generations in Cocalinho and Pé do Morro, while endogamous marriages were not observed. Exogamous marriages in Cocalinho were observed in generation 3 (19.57\%), and they were mostly matrilocal. In Pé do Morro, patrilocal marriages comprised $10 \%$ of the total, as indicated by the $\mathrm{P}$ and $\mathrm{M}$ index shown in Table 3. 
Table 2 Self-classification frequencies in the three quilombos, Brazil, North and Middle West Brazilian regions, Tocantins (TO) and Goiás (GO) states, municipalities of Aragominas (TO), Santa Fé do Araguaia (TO) and Cavalcante (GO).

\begin{tabular}{|c|c|c|c|c|c|c|c|c|c|c|c|c|c|}
\hline & \multirow{3}{*}{$\begin{array}{c}\text { Total } \\
\mathbf{N}\end{array}$} & \multicolumn{8}{|c|}{ Self-classification* } & \multirow{2}{*}{\multicolumn{2}{|c|}{ Amerindian }} & \multirow{2}{*}{\multicolumn{2}{|c|}{$\begin{array}{c}\text { No self- } \\
\text { classification }\end{array}$}} \\
\hline & & \multicolumn{2}{|c|}{ White } & \multicolumn{2}{|c|}{ Black } & \multicolumn{2}{|c|}{ Yellow (Asian) } & \multicolumn{2}{|c|}{ Mixed } & & & & \\
\hline & & $\mathbf{N}$ & $\%$ & $\mathbf{N}$ & $\%$ & $\mathbf{N}$ & $\%$ & $\mathbf{N}$ & $\%$ & $\mathbf{N}$ & $\%$ & $\mathbf{N}$ & $\%$ \\
\hline \multicolumn{14}{|l|}{ Present study } \\
\hline Kalunga & 207 & 2 & 0.97 & 120 & 57.97 & - & - & 84 & 40.58 & 1 & 0.48 & - & - \\
\hline Cocalinho & 70 & 8 & 11.43 & 46 & 65.71 & - & - & 14 & 20.00 & 2 & 2.86 & - & - \\
\hline Pé do Morro & 63 & 6 & 9.52 & 22 & 34.92 & - & - & 35 & 55.56 & - & - & - & - \\
\hline Total & 340 & 16 & 4.71 & 188 & 55.29 & - & - & 133 & 39.12 & 3 & 0.88 & - & - \\
\hline \multicolumn{14}{|c|}{ Data from 2010 demographic census (IBGE 2010) } \\
\hline Brazil & $190,755,799$ & $90,621,281$ & 47.51 & $14,351,162$ & 7.52 & $2,105,353$ & 1.10 & $82,820,452$ & 43.42 & 821,501 & 0.43 & 36,051 & 0.02 \\
\hline North & $15,864,454$ & $3,686,144$ & 23.24 & $1,033,504$ & 6.51 & 176,721 & 1.11 & $10,659,535$ & 67.19 & 305,152 & 1.92 & 3,398 & 0.02 \\
\hline Middle West & $14,058,094$ & $5,838,123$ & 41.53 & 926,905 & 6.59 & 208,743 & 1.48 & $6,951,395$ & 49.45 & 130,414 & 0.93 & 2,514 & 0.02 \\
\hline Tocantins & $1,383,445$ & 338,388 & 24.46 & 125,847 & 9.10 & 27,036 & 1.95 & 879,318 & 63.56 & 12,843 & 0.93 & 13 & 0.00 \\
\hline Goiás & $6,003,788$ & $2,487,674$ & 41.44 & 387,673 & 6.46 & 100,797 & 1.68 & $3,019,262$ & 50.29 & 8,016 & 0.13 & 366 & 0.01 \\
\hline $\begin{array}{l}\text { Aragominas - TO } \\
\text { Santa Fé do Araguaia - }\end{array}$ & 5,882 & 1,172 & 19.93 & 743 & 12.63 & 266 & 4.52 & 3,679 & 62.55 & 21 & 0.36 & - & - \\
\hline TO & 6,599 & 1,712 & 25.94 & 530 & 8.03 & 99 & 1.50 & 3,973 & 60.21 & 284 & 4.30 & - & - \\
\hline Cavalcante - GO & 9,392 & 1,205 & 12.83 & 2,670 & 28.43 & 318 & 3.39 & 5,166 & 55.00 & 34 & 0.36 & - & - \\
\hline
\end{tabular}

* Brazilian Census classificatory units used (Census of 2010 published on 2011) Source: authors, 2019. 
C)

Table 3 Distribution of categories of marriage in six quilombo communities across three generations.

\begin{tabular}{|c|c|c|c|c|c|c|c|c|c|c|}
\hline \multirow[t]{3}{*}{ 'Quilombos' } & \multirow[t]{3}{*}{ Generation } & \multirow{3}{*}{$\begin{array}{l}\text { Number of } \\
\text { Couples }\end{array}$} & \multicolumn{7}{|c|}{ Categories of marriages } & \multirow[t]{3}{*}{$p$ value } \\
\hline & & & \multicolumn{2}{|c|}{$\mathbf{E N}$} & \multicolumn{3}{|c|}{$\mathbf{E X}$} & \multicolumn{2}{|c|}{$\mathbf{B M}$} & \\
\hline & & & $\mathbf{N}$ & $\%$ & $\mathbf{N}$ & $\%$ & $P$ and $M$ & $\mathbf{N}$ & $\%$ & \\
\hline \multirow[t]{3}{*}{ Kalunga } & 1 & 242 & 223 & 92.15 & 5 & 2.07 & 0.6 & 14 & 5.78 & \multirow[t]{3}{*}{0.008} \\
\hline & 2 & 133 & 121 & 90.98 & 6 & 4.51 & 0.5 & 6 & 4.51 & \\
\hline & 3 & 126 & 120 & 95.24 & 6 & 4.76 & 0.5 & -- & -- & \\
\hline \multirow[t]{3}{*}{ Cocalinho } & 1 & 87 & -- & -- & -- & -- & -- & 87 & 100.0 & \multirow[t]{3}{*}{0.000} \\
\hline & 2 & 52 & -- & -- & -- & -- & -- & 52 & 100.0 & \\
\hline & 3 & 46 & -- & -- & 9 & 19.57 & 0.13 & 37 & 80.43 & \\
\hline \multirow[t]{3}{*}{ Pé do Morro } & 1 & 70 & -- & -- & -- & -- & -- & 70 & 100.0 & \multirow[t]{3}{*}{0.002} \\
\hline & 2 & 52 & -- & -- & -- & -- & -- & 52 & 100.0 & \\
\hline & 3 & 40 & -- & -- & 4 & 10.0 & 3 & 36 & 90.0 & \\
\hline
\end{tabular}

Chi-square test of Pearson EN: endogamous marriage, EX: exogamous marriage, BM: marriage between migrants $\mathbf{p} \leq \mathbf{0 . 0 5} \mathrm{P}$ and $\mathrm{M}$ patrilocal/matrilocal unions index was calculated for exogamous marriage and it is not included in statistical analysis. Source: authors, 2019. 


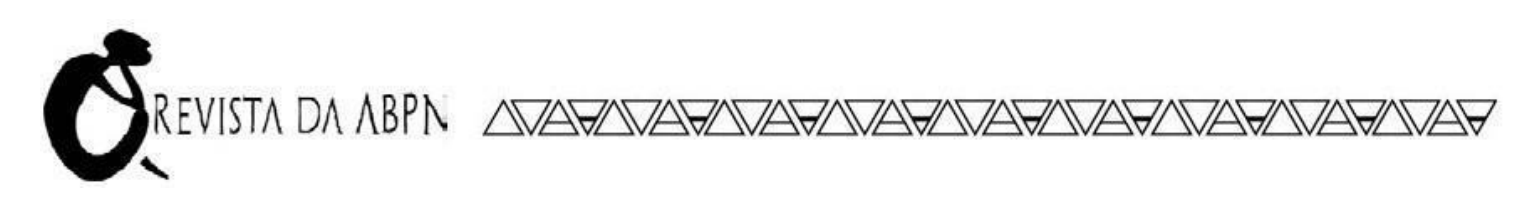




\section{DISCUSSION}

Quilombo, initially regarded as a form of political resistance against slavery and the colonial regime, has become a form of social organization and ethnic category, and a legal category found in public policy (Leite, 2015). Contemporary quilombo communities claim their origin in traditional quilombos describing themselves as part of the movement of resistance to oppression during and after the slavery period and as being descendants of rebel slaves who took up residence on the margins of society. However, it is difficult to find historical documentation of the origin and history of these population and usually their stories are passed down via oral narratives (Funari, 1996; Lopes, 2009).

In this study we documented two examples of demographic composition of quilombo communities: one formed primarily by migrant individuals, we denominated migration's quilombo, and another one composed primarily of individuals with their ancestors in the community for at least three generations, we denominated historical quilombo. These communities are heterogeneous and have shaped its populations across the three most recent generations. The main form of information about their formation and histories is oral history.

The settlement of Central Brazil region by non-indigenous populations started in the 17th century, and intensified with the discovery of gold in the Goiás region. At that point, this region was invaded by explorers, missionaries, ranchers and adventurers in search of gold. From these early explorations emerged settlements made up of simple huts which eventually became urban centers, primarily peopled by families of descendants of enslaved Africans (Lopes, 2009).

Kalunga quilombo is composed of descendants of enslaved Africans who were taken to work in the "Mines of Tocantins", in an area where today the city of Monte Alegre is located. According to Soares (1995), slaves fled from the mines in the late 18th century and formed the quilombo. However, residents indicated that their ancestors were abandoned by the pioneers when the gold mines were exhausted and, fearing capture again, they remained hidden for decades without contacting the outside world. In 1982 anthropologists drew attention to the construction of a hydroelectric plant in Rio Paranã, which would harm hundreds of Kalunga people. At that point, there was no information 
about this people, and soon after they started the process of claiming their lands (Baiocchi, 1996). Over time, towns and cities grew near their area and they started trading relations with the inhabitants of urban centers (Meegen-Silva, 1999). Therefore, Kalunga fits the traditional definition of a quilombo. Since 1991, their area was officially recognized by the state government of Goiás as a historical site - Cultural Heritage Kalunga. However, only in 2001, Fundação Cultural Palmares (2016) recognized the rights to culture and to collective property for Kalunga quilombo.

Oral narratives from the members of Cocalinho and Pé do Morro quilombos communities also shed light about how their communities were settled. Most participants indicated that their families were pioneer families, mostly from State of Maranhão (located in the Northeast of Brazil), who settled in the region in search of land and possibly better jobs. In the past, Maranhão state had a large number of slave-owning families, a fact that led to the formation of a significant number of quilombos in this Brazilian State (Fiabani, 2008). Since the late 19th century, the population of the Brazilian Northeast region has suffered from intense periods of drought, which triggered migration flows to the Brazilian North region (Costa, 2015).

The first descendants-of-slaves settlers arrived in the north of Tocantins at the beginning of 20th century. More of these landless peasants (campesinos) kept arriving, and were part of the migratory movements in search of land and work that peaked in the 1950's in Brazil (Velho, 2009). According to researchers, the migration of rural Black communities from Maranhão to the North region was not only associated with economic necessity, but also with keeping family groups together (Gomes 2011; Santos 2015). Therefore, the communities that were formed beginning in the early $20^{\text {th }}$ Century, but continually through the $20^{\text {th }}$ Century, were peopled by migrants who were, in many cases, related or who had some cultural cohesion, as they migrated from the same region.

Cocalinho and Pé do Morro were officially recognized by Fundação Cultural Palmares (2016) as quilombo in 2005 and 2010, respectively. The history and recent formation of these two quilombos do not fit the common sense of quilombo, but do fit the current definition and exemplifies the diversity of quilombo communities. According to Florentino and Amantino (2012), quilombo definition is evident in the absence of taxonomies, which envision quilombos as effectively historical structures, which might 
have been restricted merely to loose groups or have developed into self-sustaining communities capable of reproducing themselves economically and demographically for long periods in the Americas. These communities are inserted in multicultural societies with a high degree of ethnic-racial diversity and historical economic plurality (Florentino and Amantino, 2012).

In this study we provided evidences about the historical foundation of three quilombos using migration patterns. We were able to reconstruct the marriage structure history during the last three generations in the three quilombos. It is very clear that the level of endogamous marriage observed in Kalunga was much higher than in the other two quilombos both presently and in the past. A predominance of endogamous marriages was observed over the three generations investigated, and the few migrants (3) we sampled were all male. This result suggests that migration is gender-biased so that more men are likely to migrate into the community. The absence of migrants in Kalunga is probably due to Kalunga's location and lack of resources such as roads, electricity, running water and low possibility of irrigation, which make Kalunga a less-than-desirable destination. In Cocalinho, exogamous matrilocal marriages were more common than patrilocal marriages, which in fact is associated with the increased mobility of males in search of work (Oliveira and Jannuzzi, 2005). In Pé do Morro, we observed a predominance of marriages between migrants. Moreover, we observed that there are older migrants there than in other quilombos. In general, the number of marriages between migrants decreases across generations. This is due to the fact that community members take more control of community resources during the process of registration of land (Véran, 2000). In different quilombos from the Northeast of Brazil, it was observed a predominance of endogamous marriages and an intermediate proportion of marriages between migrants (Amorim et al., 2011) when we compared to our quilombos.

Although phenotypic self-classification is an important aspect to recognition as a member of a quilombo, these groups display all or some of the following characteristics: definition of an ethnicity, rituals or religiousness, common origin or ancestry, kinship bonds, relation to slavery, and especially a connection with their territories (Marques and Gomes, 2013). For Afro-derived communities, cultural recognition, a connection to African ancestry, and cultural traditions have become a primary way of obtaining 
collective land rights and social inclusion (Farfán-Santos, 2015; Brazil, 2006). Since 2007, the government has requested documentation about the history of the quilombos communities; however, many if not most quilombos are unable to provide written documentation of their history, and rely on oral tradition as their sole historiographical source.

Public policies such as Brazil Quilombolas Program intend to promote equal opportunities for individuals from the quilombos, and have become an important slavery reparation program. In 2003, the government of President Luiz Inácio 'Lula' da Silva expanded the legal definition of the term quilombo issuing a presidential decree (Decree No. 4.887, November, 20, 2003) according to which quilombos are "ethno-racial groups, according to self-classification criteria, with their own historical trajectory, associated to their own land, established as part of the resistance to oppression, and with presumed African ancestry related to resistance suffered during historic oppression". According to Brazilian law, people have the right to define their own ethnicity for the purposes of social policy, and the residents of quilombos have a constitutional right to the land settled by their ancestors. Despite such policies, some quilombos see themselves threatened by other members of Brazilian society, who may argue that if the quilombos are unable to prove ownership of the land, or if the group does not fit the "mythical" definition of a quilombo, then the land does not belong to the quilombo.

Affirmative action and public policies intended to promote equal opportunities for people of all ancestries are being implemented in Brazil over the past decade and may have helped promote a sense of self-esteem and, consequently, to an increase in the number of people who classify themselves in the categories "mixed" and "black". Indeed, in the two last Brazilian census, the proportion of people self-classified as black and mixed increased from $6.2 \%$ to $7.6 \%$, and from $38.5 \%$ to $43.1 \%$, respectively (IBGE, 2011).

The importance of highlighting the ethnic-racial dimension in population studies is, at least in part, due-the recognition of the historical discrimination that African peoples and their descendants suffered and that resulted in conditions of marginalization and vulnerability. 
Although there are differences in the struggle and history of resistance among quilombos, their geographical proximity to urban centers or even overlapping with cities possibly contributes to a new quilombo identity. Accordingly, in order to establish the rights of Afro-derived communities in Brazil, such as the balance between universalist and affirmative action policies, the partial convergence between poverty and racial discrimination and the historical legacy of discrimination in Brazilian society, it is necessary to consider that quilombos may have different beginnings and histories (Ikawa, 2009; Telles and Paixão, 2013).

Despite the quilombos share common traits, such as subsistence based on rural life with the collective use of land, the origin related to slavery, peasantry, ethnic-racial relations among several groups, there is no single characteristic that is more important in all recognized communities. Considering the discussions about ownership and recognition, the quilombos came to be called quilombola communities and / or contemporary quilombos. They were transformed in movement associated with the land rights. Although there are numerous communities in Brazil (more than 2,600 registered communities), these communities do not present a significant population density, and they are represented by families occupying an area corresponding to $0.12 \%$ of the national territory (IBGE, 2011). These populations are considered, by anthropology and the Brazilian government as distinct from other Brazilian rural populations when we consider historical and cultural characteristics. Decree No. 6.040, of February 7, 2007, refers to the term traditional populations and communities as "culturally differentiated groups that are recognized as such, which have their own forms of social organization, which occupy and use territories and natural resources as condition for its cultural, social, religious, ancestral and economic reproduction, using knowledge, innovations and practices generated and transmitted by tradition." (Author's free translation). New meanings have been built on the terms remnants of quilombos and quilombos, since there is a diversity of formation histories, representing this term a social category for governmental discussions and public policies (Mattos, 2003; O 'Dwyer, 2007).

\section{CONCLUSION}


We have sought to analyze the meaning of quilombo through examples based on our field research carried out in Central Brazil region Afro communities. Our aim in this article has been to illustrate the meaning of quilombo using a different approach such as historical circumstances and diversity in the migration patterns. This approach allow us to loosely sort them into two examples: communities that were formed by either run-away or abandoned slaves (historical quilombos) or communities not directly related to the history of slavery, but associated with the migration of rural land-less Black communities after the abolition of slavery (migrant quilombos). The lack of agreement on the definition of quilombo is a debate that involves economic and social interests of different parts of Brazilian society, as the meaning of the concept is indissociably tied from the historical 'ideal' of what a quilombo "should" be (Center, 2008). Therefore, it is critical to stress that many communities that were historically discriminated may be at risk of losing their land. If there are quilombos, it is because a group achieved political autonomy and social organization to have a territory and fight for better living conditions at a historical moment. However, different groups arrived at their own historical moments in different ways. Therefore, we highlight the quilombo communities represent a struggle for rights and for a consciousness about the African diaspora and its descendants.

\section{ACKNOWLEDGMENTS}

We warmly thank the quilombos (Cocalinho, Kalunga, and Pé do Morro), and their associations for sharing their time and life history with us. We are also grateful to Secretaria Municipal de Saúde de Cavalcante and Federal Institute of Tocantins campus Araguaína for their assistance during the development of fieldwork. We thank to Rosa Maria Machado de Sena, Ana Flávia de Morais Oliveira, Rafaela de Cesare Parmezan Toledo, and all staff for valuable assistance with the interviews. We thank to Matheus de Castro Nóbrega for orgarnization of data bank. A special thank to Mecca Burris for her English review. We also thank to Tatiana Oliveira Novais, Maria Clorinda Soares Fioravanti, and Gerson Alves de Oliveira for introducing members of quilombos to us. Grant sponsors: Conselho Nacional de Desenvolvimento Científico e Tecnológico 
(CNPq), Coordenacão de Aperfeiçoamento de Pessoal de Nível Superior (CAPES), Brazil, and Programa de Extensão Universitária (Proext)/Ministry of Education

\section{REFERENCES}

ABA, Associação Brasileira de Antropologia. Grupo de trabalho Quilombos, Brasília- Distrito Federal, 2012 Available: https://docplayer.com.br/43125299-Associacao-brasileira-deantropologia-aba-grupo-de-trabalho-quilombos-2012.html Accessed: 03/01/2014.

ANJOS, Rafael Sanzio Araújo dos. Cartography of the African-Brazilian Diaspora. Revista da ANPEGE, v.7, n.1, p. 261-274, 2011.

AMORIM, Carlos Eduardo; GONTIJO, Carolina Carvalho; FALCÃO-ALENCAR, Gabriel; GODINHO, Neide M.O; TOLEDO, Rafaela C.P.; PEDROSA, Maria Angélia F.; LUIZON, Marcelo R.; SIMÕES, Aguinaldo L.; KLAUTAU-GUIMARÃES, Maria N.; OLIVEIRA, Silviene F. Migration in Afro-Brazilian rural communities: crossing demographic and genetic data. Human Biology, v. 83, n.4, p.509-21, 2011.

ANTÓN, Jhon; BELLO, Álvaro; DEL POPOLO, Fabiana; PAIXÃO, Marcelo; RANGEL, Marta. Afrodescendientes en América Latina y el Caribe: del reconocimiento estadístico a la realización de derechos. Santiago de Chile, 2009.

BAIOCCHI, Maria de Nasaré. Kalunga. A sagrada terra. Revista da Faculdade de Direito. UFG, v. 19/20, n.1, p.107-120, 1996.

BRAZIL, Maria do Carmo. Formação do campesinato negro no Brasil Reflexão categorial sobre os fenômenos "quilombo", "remanescente de quilombo" e "comunidade negra rural": Encontro de História de Mato Grosso do Sul. Dourados - Mato Grosso do Sul, 2006.

CENTER, Rapoport. Between the Law and Their Land: Afro-Brazilian 'Quilombo Communities' Struggle for Land Rights A Report by the Rapoport Delegation on Afro-Brazilian Land Rights: The University of Texas at Austin School of Law, 2008.

CHAGAS, Miriam de Fátima. A política do reconhecimento dos "remanescentes das comunidades dos quilombos". Horizontes Antropológicos, v. 7, n.15, p. 209-235, 2001.

COSTA, Carlos Eduardo Coutinho da. Migrações negras no pós-abolição do sudeste cafeeiro (1888-1940). Topoi (Rio de Janeiro), v. 16, n. 30, p.101-126, 2015.

DECREE NO. 4.887, NOVEMBER, 20, 2003 Available: http://www.planalto.gov.br/ccivil_03/decreto/2003/d4887.htm Accessed: 05/03/2014.

DECREE NO. 6.040, of February 7, 2007 Available: http://www.planalto.gov.br/ccivil_03/_Ato2007-2010/2007/Decreto/D6040.htm Accessed:05/03/2014. 
FARFÁN-SANTOS, Elizabeth. "Fraudulent" Identities: The Politics of Defining Quilombo Descendants in Brazil. The Journal of Latin American and Caribbean Anthropology, v. 20, n.1, p.110-132, 2015.

FIABANI, Aldemir. Os Novos Quilombos Luta pela terra e afirmação étnica no Brasil (19882008). Tese (Doutorado em História). Universidade do Vale do Rio dos Sinos - UNISINOS, São Leopoldo/RS, 2008.

FILHO, Diosmar M. Santana; GERMANI, Guiomar Inez. A IDENTIDADE POLÍTICA E SOCIAL QUILOMBOLA NO BRASIL DO SÉCULO XXI. Revista da Associação Brasileira de Pesquisadores/as Negros/as (ABPN), [S.1.], v. 6, n. 12, p. 78-101, fev. 2014.

FLORENTINO, Manolo; AMANTINO, Márcia. Uma morfologia dos quilombos nas Américas, séculos XVI-XIX*A morphology of 'quilombos' in the Americas, sixteenth-nineteenth centuries. História, Ciências, Saúde v.19, p. 259-297, 2012.

FUNARI, Pedro Paulo A. A arqueologia de Palmares: Sua contribuição para o conhecimento da história da cultura afro-americana. In: Liberdade por um fio. REIS, João José; GOMES. Flávio dos Santos. 26-51. São Paulo: Cia das Letras, 1996.

FUNDAÇÃO CULTURAL PALMARES. Comunidades certificadas. Palmares Fundação Cultural website. http://www.palmares.gov.br/wpcontent/uploads/2016/06/COMUNIDADES-

CERTIFICADAS.pdf. 2016. Accessed: 11/24/2016.

GOMES, Flávio. Africanos e crioulos no campesinato negro do Maranhão oitocentista. Outros tempos Dossiê História e Literatura v. 8, n.11, 2011.

GOMES, Flávio dos Santos. Mocambos e Quilombos. Uma história do campesinato negro no Brasil. São Paulo: claroenigma, 2015.

IBGE, Instituto Brasileiro de Geografia e Estatística. Censo Demográfico 2010: Características da População e dos Domicílios. Resultados do Universo. Rio de Janeiro, 2011.

IKAWA, Daniela. The Right to Affirmative Action for Blacks in Brazilian Universities. The Equal Rights Review, v.3, p.28-37, 2009.

KARASCH, Mary. Os quilombos do ouro na capitania de Goiás. In: REIS, João José; GOMES, Flávio dos Santos (Orgs.). Liberdade por um fio: história dos quilombos no Brasil. São Paulo: Companhia das Letras, 1996. p. 240-262.

LARA, Silvia Hunold. Palmares and Cucaú: Political Dimensions of a Maroon Community in Late Seventeenth-Century Brazil. In: American Counterpoint: New Approaches to Slavery and Aboliton in Brazil, 12th Annual Gilder Lehrman Center, Yale University, New Haven, CT, 2010.

LEITE, Ilka Boaventura. The Brazilian quilombo: 'race', community and land in space and time, The Journal of Peasant Studies, v.42, n.6, p.1225-1240, 2015.

LOPES, Maria Aparecida de Oliveira. Experiências históricas dos quilombolas no Tocantins: organização, resistência e identidades. Patrimônio e Memória v.5, n.1, p.107-126, 2009. 
MARQUES, Carlos Eduardo; GOMES, Lílian. A Constituição de 1988 e a ressignificação dos quilombos contemporâneos Limites e potencialidades. Revista Brasileira de Ciências Sociais, v.28, n.81, 2013.

MATTOS, Hebe. "Remanescentes das comunidades dos quilombos": memória do cativeiro e políticas de reparação no Brasil. Revista USP. v.68, p.104-111, 2006.

MEEGEN-SILVA, Ana van. Kalunga: Identidade Etnica de uma comunidade Remanescentes de Quilombos. Vrije Universiteit. Amsterda, Holanda, 1999.

O'DWYER, Eliane Cantarino. Terras de quilombo: identidade étnica e os caminhos do reconhecimento. Revista TOMO, v.11, p.43-58, 2007.

OLIVEIRA, Kleber Fernandes de; JANNUZZI, Paulo de Martino. Motivos para migração no Brasil e retorno ao Nordeste padrões etários, por sexo e origem/destino. São Paulo em Perspectiva. v.19, n.4, p.134-143, 2005.

POPOLO, Fabiana Del; DA CUNHA, Estela Maria Garcia de Pinto; RIBOTTA, Bruno; AZEVEDO, Marta. Pueblos indígenas y afrodescendientes en América Latina: dinámicas poblacionales diversas y desafíos comunes. A. Editor, ed., 2011.

SANTOS, Maria Emília Vasconcelos dos. Mobilidade dos trabalhadores dos engenhos na abolição e no pós-abolição: trajetórias e autonomia (Zona da Mata Sul, 1884-1893). In: XXVIII Simpósio Nacional de História Lugares dos Historiadores: velhos e novos desafios. Florianópolis, 2015.

SEPPIR, Secretaria de Políticas de Promoção da Igualdade Racial Programa Brasil. Quilombola. Diagnóstico de Ações Realizadas, Brasília, Distrito Federal, 2012. Accessed: 01/01/2014.

SETIA, Maninder Singh. Methodology Series Module 3: Cross-sectional Studies. Indian Journal of Dermatology.v.61,n.3, p.261-264, 2016.

SILVA, Simone Rezenda da. A trajetória do negro no Brasil e a territorialização quilombola. Revista NERA v.14, n.19, p.73-89, 2011.

SOARES, Aldo Asevedo. Kalunga: O direito de Existir, Questões Antropológicas e Jurídicas sobre Remanescentes de Quilombo. Goiânia: MinC/Fundação Cultural Palmares, 1995.

TELLES, Edward; PAIXÃO, Marcelo. Affirmative Action in Brazil. Lasaforum XLIV, v.2, 2013.

TORRE, Oscar de La "Are they really quilombos?" Black peasants, politics, and the meaning of quilombo in present-day Brazil. Journal of Transatlantic Studies 3 v. (1 and 2), p. 97-118, 2013.

VELHO, Otávio Guilherme. Frente de expansão e estrutura agrária: estudo do processo de penetração numa área da Transamazônia [online]. Rio de Janeiro: Centro Edelstein de Pesquisas Sociais, 2009. Available in: http://books.scielo.org/id/zjf4z/pdf/velho-9788599662915.pdf

VÉRAN, Jean François. Rio das Rãs: memória de uma "comunidade remanescente de quilombo". Afro-Ásia, v.23, p. 295-323, 2000. 
Recebido 30/03/2020

Aprovado em 30/04/2020 